\title{
Genetic diagnosis of congenital hypopituitarism by a target gene panel: novel pathogenic variants in GLI2, OTX2 and GHRHR
}

\author{
Marilena Nakaguma ${ }^{1}$, Fernanda A Correa ${ }^{1}$, Lucas S Santana ${ }^{2}$, Anna F F Benedetti ${ }^{1}$, Ricardo V Perez ${ }^{3}$, \\ Martha K P Huayllas ${ }^{4}$, Mirta B Miras ${ }^{5}$, Mariana F A Funari ${ }^{1}$, Antonio M Lerario ${ }^{6}$, Berenice B Mendonca ${ }^{1}$, \\ Luciani R S Carvalho ${ }^{1}$, Alexander A L Jorge ${ }^{2}$ and Ivo J P Arnhold ${ }^{1}$
${ }^{1}$ Unidade de Endocrinologia do Desenvolvimento, Laboratório de Hormônios e Genética Molecular LIM42, Disciplina de Endocrinologia, Hospital das Clínicas da Faculdade de Medicina da Universidade de São Paulo, São Paulo, Brasil
2Unidade de Endocrinologia Genética, Laboratório de Endocrinologia Celular e Molecular LIM25, Disciplina de Endocrinologia, Hospital das Clínicas da Faculdade de Medicina da Universidade de São Paulo, São Paulo, Brasil
${ }^{3}$ Serviço de Endocrinologia, Hospital do Servidor Público Estadual de São Paulo, Instituto de Assistência Médica ao Servidor Público Estadual (HSPE- IAMSPE), São Paulo, Brasil
${ }^{4}$ Hospital de Transplantes Euryclides de Jesus Zerbini, São Paulo, Brasil
${ }^{5}$ Hospital de Niños Santísima Trinidad, Cordoba, Argentina
${ }^{6}$ Department of Internal Medicine, Division of Metabolism, Endocrinology and Diabetes, University of Michigan, Ann Arbor, Michigan, USA

Correspondence should be addressed to IJ P Arnhold: iarnhold@usp.br

\begin{abstract}
Aim: Congenital hypopituitarism has an incidence of 1:3500-10,000 births and is defined by the impaired production of pituitary hormones. Early diagnosis has an impact on management and genetic counselling. The clinical and genetic heterogeneity of hypopituitarism poses difficulties to select the order of genes to analyse. The objective of our study is to screen hypopituitarism genes (candidate and previously related genes) simultaneously using a target gene panel in patients with congenital hypopituitarism. Methods: Screening of 117 subjects with congenital hypopituitarism for pathogenic variants in 26 genes associated with congenital hypopituitarism by massively parallel sequencing using a customized target gene panel.

Results: We found three novel pathogenic variants in OTX2 c.295C>T:p.GIn99*, GLI2 c.1681G>T:p.Glu561* and GHRHR c.820_821 insC:p.Asp274Alafs*113, and the previously reported variants in GHRHR c.57+1G>A and PROP1 [c.301_302delAG];[c.109+1G>A]. Conclusions: Our results indicate that a custom-designed panel is an efficient method to screen simultaneously variants of biological and clinical relevance for congenital GH deficiency. A genetic diagnosis was possible in 5 out of 117 (4\%) patients of our cohort. We identified three novel pathogenic variants in GHRHR, OTX2 and GLI2 expanding the spectrum of variants associated with congenital hypopituitarism.
\end{abstract}

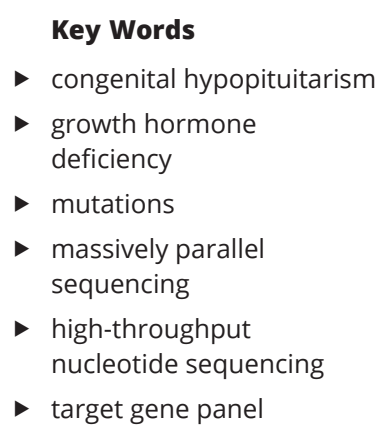

Endocrine Connections (2019) 8, 590-595

\section{Introduction}

Congenital hypopituitarism $(\mathrm{CH})$ is a rare disorder (incidence of 1:3500-10,000 births) defined by the deficiency of one or more pituitary hormones $(1,2)$. Clinical presentation varies, ranging from isolated growth hormone deficiency (IGHD) to combined pituitary hormone deficiencies (CPHD). CH also varies with respect to hypothalamic-pituitary anatomy from normal magnetic resonance imaging to the presence of midline defects such as pituitary stalk interruption syndrome (PSIS) and/or severe complex https://ec.bioscientifica.com https://doi.org/10.1530/EC-19-0085 (c) 2019 The authors Published by Bioscientifica Ltd

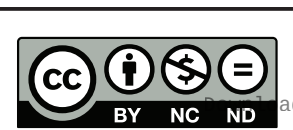

This work is licensed under a Creative Commons Attribution-NonCommercial-NoDerivatives 4.0 Internationab bicense.ifica.com at 04/26/2023 06:26:45AM 
craniofacial malformations, such as septo-optic dysplasia (SOD).

The genetic defects leading to $\mathrm{CH}$ were classified in: defects in $\mathrm{GH}$ secretion (GH1, GHRHR); defects in pituitary cell differentiation (PROP1, POU1F1) and defects in pituitary development (such as HESX1, GLI2, OTX2) (2). The most common genes implicated are those encoding GH1 and GHRHR in IGHD and PROP1 in CPHD, especially in certain geographical regions. Until now, most studies used the candidate-gene approach as the main strategy to identify the genetic cause of $\mathrm{CH}$ (3). As this strategy considers the patient's clinical presentation to guide the molecular investigation, genes were heterogeneously screened in most studies - the same genes were not analysed in the entire cohort. Moreover, as the clinical phenotype is highly variable, we cannot assure that all possible causative genes were excluded (4). The use of massive parallel sequencing, mostly targeted sequencing panel or whole exome sequence (WES), allows the screening of several genes simultaneously with high accuracy in a less time-consuming way.

In the present study, we developed a comprehensive gene panel for systematic assessment of $\mathrm{CH}$ including previously known and newly discovered genes related to $\mathrm{CH}$ in a large cohort with the objective of expanding the clinical and etiological spectrum of this disease.

\section{Patients and methods}

Patients with $\mathrm{CH}$ followed at the Unidade de Endocrinologia do Desenvolvimento (São Paulo, Brazil) and Hospital de Niños Santísima Trinidad (Cordoba, Argentina) with previous positive genetic diagnosis by
Sanger sequencing with the candidate-gene approach were not included in this study. We selected 117 subjects with $\mathrm{CH}$ of unknown cause (104 from Brazil and 13 from Argentina) (Fig. 1). The patients were predominantly male (55\%, $n=64)$, only eight were born from consanguineous parents and another 25 had relatives with short stature. Most of them had CPHD (77\%, $n=90)$ and ectopic posterior pituitary (EPP) lobe $(68 \%, n=79)$ (Fig. 1). The median age of the first visit was 11 years (ranging from 6 days to 51.9 years), height SDS of -3.8 (ranging from -1.8 to -7.4 ) and $\mathrm{GH}$ peak of $1.7 \mu \mathrm{g} / \mathrm{dL}$ (ranging from undetectable to $4.7 \mu \mathrm{g} / \mathrm{dL}$ ). This study was approved by the respective Local Ethics Committees ('Comitê de Ética para Análise de Projetos de Pesquisa' in Brazil and 'Comité Institucional de Ética de la Investigación en Salud del Niño y del Adulto' in Argentina) and the patients or guardians gave their written informed consent.

Serum levels of TSH, GH, LH, FSH, PRL, cortisol, dehydroepiandrosterone sulphate, total thyroxine, free thyroxine, insulin-like growth factor 1 (IGF-1), oestradiol or testosterone levels were measured at baseline. Stimulatory tests were performed for the diagnosis of $\mathrm{GH}$ and other pituitary hormone deficiencies as previously described (5). In neonates, $\mathrm{GH}$ (cut-off limit $<5 \mathrm{ng} / \mathrm{mL}$ ) deficiency was evaluated considering the baseline GH measurement during hypoglycaemia and IGF-1 and IGFBP-3 levels less than -2 SDS for age and sex. As patients were studied at different centres using different hormonal assays, normal ranges of each centre were considered.

\section{Target gene panel}

Genomic DNA was extracted from peripheral blood leucocytes of all patients. A customized gene panel was

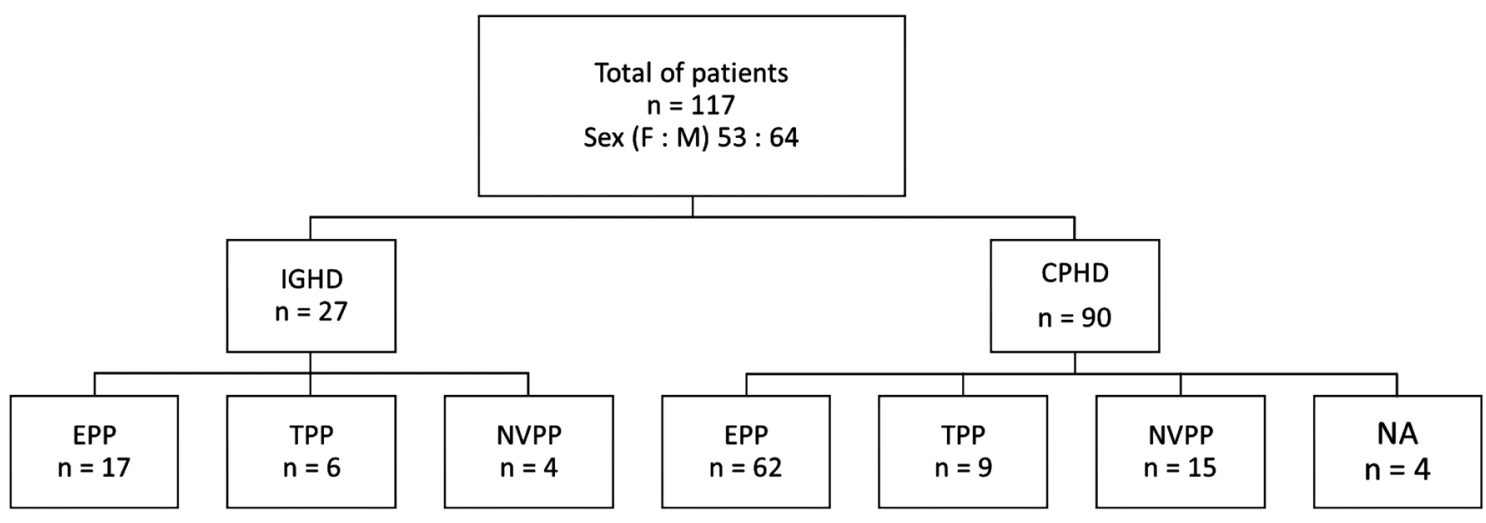

Figure 1

Clinical features of sequenced patients. CPHD, combined pituitary hormone deficiency; EPP, ectopic posterior pituitary lobe; IGHD, isolated growth hormone deficiency; NA, not available; NVPP, non-visualized posterior pituitary; TPP, topic posterior pituitary lobe.

https://ec.bioscientifica.com https://doi.org/10.1530/EC-19-0085 (c) 2019 The authors Published by Bioscientifica Ltd

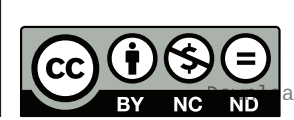

This work is licensed under a Creative Commons Attribution-NonCommercial-NoDerivatives 4.0 delnternationad bicense.ifica com at 04/26/2023 06:26:45AM 
designed using Agilent Sure Design (Agilent Technologies, Inc.) with probes for 26 genes previously related to hypopituitarism GH1, GHRH, GHRHR, GHSR, PROP1, POU1F1, GLI2, HESX1, LHX3, LHX4, OTX2, PITX2, ARNT2, DMXL2, FGF8, FGFR1, GPR161, HHIP, IGSF1, KAL1, PROKR2, RNPC3, SHH, SOX2, SOX3 and TGIF1 (2).

Genomic DNA was mechanically fragmented using Covaris. Libraries were constructed using SureSelect Target Enrichment System Technology in accordance with the manufacture's protocols (Agilent Technologies). The sequences were generated in the Illumina NextSeq 500 platform running on paired-end mode. Reads were aligned to the GRCh37/hg19 assembly of the human genome with the Burrows-Wheeler aligner (BWA-MEM) (GNU General Public License version 3.0 (GPLv3), MIT License, Cambridge, MA, USA). Variant calling was performed with Freebayes (https://wiki.gacrc.uga.edu/wiki/Freebayes) and the resulting variant call formats (VCFs) were annotated with ANNOVAR (http://annovar.openbioinformatics.org/ en/latest/).

The targeted panel sequencing data were screened for rare variants $(\mathrm{MAF}<1 \%)$ in public global and Brazilian databases: gnomAD (http://gnomad.broadinstitute. org/) and ABraOM (http://abraom.ib.usp.br/), located in exonic regions and consensus splice site sequences. Next, our variant filtration prioritized genes based on their potential to be pathogenic: loss-of-function (LoF) variants and variants predicted to be pathogenic by multiple in silico programmes (SIFT, PolyPhen2, Mutation Taster, PROVEAN and CAAD). The sequencing reads carrying candidate variants were inspected visually using the Integrative Genomics Viewer (IGV) to reduce false-positive calls. Sanger sequencing confirmed all pathogenic and probably pathogenic variants. (Primer sequence and amplification protocols are available upon request.) The variants at the final list were assessed for the clinical interpretation of pathogenicity using InterVar (http://wintervar.wglab.org/) according to the American College of Medical Genetics and Genomics/ Association for Molecular Pathology (ACMG/AMP) variant pathogenicity guidelines (6).

\section{Results}

\section{Molecular results}

The median coverage depth of the coding regions in our panel data was $462 \times$, with at least $99.6 \%$ of the sequenced bases covering more than 20 -fold.
We identified causative pathogenic variants in 5 of $117 \mathrm{CH}$ patients (diagnostic yield of 4\%) (Table 1). These variants were in genes directly involved in $\mathrm{GH}$ secretion (GHRHR), in pituitary cell differentiation (PROP1) and in pituitary development (GLI2, OTX2). All variants were absent or extremely rare in local and public databases (Table 1).

Biallelic LoF variants were identified in GHRHR and PROP1 genes. One pathogenic mutation located in a consensus splice site (c.57+1G>A) and another causing a frameshift mutation (c.820_821insC:p.Asp274Alafs*113) in GHRHR were found in homozygous state, each in one patient with IGHD. Two pathogenic variants in PROP1 were identified in compound heterozygous state in one patient with CPHD by this panel and has been recently published with a cohort of PROP1 Brazilian patients (7).

Two novel heterozygous nonsense pathogenic variants were identified in GLI2 (c.1681G>T:p.Glu561*) and OTX2 (c.295C>T:p.Gln99*), each one in one subject.

\section{Phenotype of subjects with variants of interest}

Characteristics of affected subjects are detailed in Table 2. Weight, length at birth, GH peak, age and height SDS at first visit did not differ significantly from those with negative molecular results. All patients were severely affected at presentation (median height SDS of -5.8 , ranging from -7.8 to -4.4 ) (Table 2 ).

Among the patients with homozygous variants in GHRHR, one patient was born to consanguineous parents and the other patient's parents came from the same small village and probably presented some degree of consanguinity. The second case had a short brother and the presence of the same variant was identified in homozygous state by Sanger sequencing.

The patients carrying variants in GHRHR had IGHD and topic posterior pituitary (TPP). The patient with PROP1 mutation had CPHD (GH, TSH and partial ACTH deficiencies) and TPP.

Patients with pathogenic variant in genes precociously expressed during hypothalamic-pituitary development, GLI2 and OTX2, presented IGHD and EPP.

The mother of the patient with GLI2 variant, also carrying the same mutation, has short stature (-4.0 HSDS), EPP, hypoplasia of anterior pituitary and thin stalk, despite having IGF-1 levels in the normal range for her advanced age. The index patient's mother referred that her brother and nephew (not available for clinical or genetic studies) had polydactyly.

This work is licensed under a Creative Commons Attribution-NonCommercial-NoDerivatives 4.0 Internationab bicense ifica.com at 04/26/2023 06:26:45AM 
Table 1 Pathogenic variants identified by targeted panel sequencing in a cohort of 117 patients with congenital hypopituitarism.

\begin{tabular}{|c|c|c|c|c|c|c|c|c|}
\hline Patient & Gene & Allelic variant & GnomAD & ABraOM & Inheritance & $\begin{array}{l}\text { Evidence of } \\
\text { pathogenicity } \\
\text { according to } \\
\text { ACMG/AMP }\end{array}$ & $\begin{array}{l}\text { Final ACMG/AMP } \\
\text { classification }\end{array}$ & RefSeq ID \\
\hline 1 & GHRHR & c. $57+1 G>A$ & 0.00001957 & 0 & Homozygous & PVS1, PM2, PP3 & Pathogenic & $\begin{array}{l}\text { NM_000823.3 } \\
\text { rs2302022 }\end{array}$ \\
\hline 2 & GHRHR & $\begin{array}{l}\text { c.820_821insC: } \\
\text { p.Asp274Alafs*113 }\end{array}$ & 0 & 0 & Homozygous & PVS1, PM2, PP3 & Pathogenic & NM_000823.3 \\
\hline \multirow[t]{2}{*}{3} & PROP1 & $\begin{array}{l}\text { c.301_302del: } \\
\text { p.Leu102Cysfs*8 }\end{array}$ & 0,0001805 & 0 & $\begin{array}{l}\text { Compound } \\
\text { Heterozygous }\end{array}$ & PVS1, PM1, PP5 & Pathogenic & $\begin{array}{l}\text { NM_006261.4 } \\
\text { rs193922688 }\end{array}$ \\
\hline & & c. $109+1 G>A$ & 0 & 0 & $\begin{array}{l}\text { Compound } \\
\text { Heterozygous }\end{array}$ & PVS1, PM2, PP3 & Pathogenic & NM_006261.4 \\
\hline 4 & $G L / 2$ & c.1681G>T:p.Glu561* & 0 & 0 & Heterozygous & PVS1, PM2, PP3 & Pathogenic & NM_005270.4 \\
\hline 5 & OTX2 & c.295C>T:p.Gln99* & 0 & 0 & Heterozygous & PSV1, PM2, PP3 & Pathogenic & NM_172337.2 \\
\hline
\end{tabular}

PVS1, null variant (nonsense, frameshift, canonical \pm 1 or 2 splice sites, initiation codon, single or multiexon deletion) in a gene where LoF is a known mechanism of disease; PM1, located in a mutational hot spot and/or critical and well-established functional domain (e.g. active site of an enzyme) without benign variation; PM2, absent from controls (or at extremely low frequency if recessive) in Exome Sequencing Project, 1000 Genomes Project, or Exome Aggregation Consortium; PP3, multiple lines of computational evidence support a deleterious effect on the gene product; PP5, reputable source recently reports variant as pathogenic, but the evidence is not available to the laboratory to perform an independent evaluation.

The patient carrying the mutation in OTX2 had microphthalmia, nystagmus and neuropsychomotor developmental delay.

\section{Discussion}

In this study, we screened simultaneously 26 genes in a cohort of 117 patients with $\mathrm{CH}$ using a target gene panel approach and identified five causative pathogenic variants (positive yield of $4 \%$ ) in genes GHRHR, PROP1, GLI2 and OTX2. A limitation of this study is that this cohort included, in addition to patients who were not sequenced before, patients in whom some candidate genes had been negative by Sanger sequencing. Therefore, a higher yield might be expected in a prospective cohort.

We found two null homozygous mutations in GHRHR in two patients and, as expected, both patients had IGHD with orthotopic posterior pituitary lobe. One variant was a frameshift insertion described for the first time in the present study and the other was a splicing mutation (c.57+1G $>$ A) initially reported in a large kindred with isolated GH deficiency from Itabaianinha in Northeastern Brazil (8). The same variant in homozygous and compound heterozygous state was also previously described in other Brazilian familial and sporadic cases and a founder effect was demonstrated (9). Most patients with autosomal recessive IGHD have variants in GHRHR

Table 2 Clinical characteristics of patients with pathogenic variants.

\begin{tabular}{|c|c|c|c|c|c|c|c|}
\hline Patients & Gene & Sex & Delivery & $\begin{array}{l}\text { Family } \\
\text { history }\end{array}$ & $\begin{array}{l}\text { Height SDS } \\
\text { at first visit }\end{array}$ & $\begin{array}{l}\text { Hormonal } \\
\text { deficiency }\end{array}$ & MRI \\
\hline $1^{a}$ & $\overline{G H R H R}$ & $\mathrm{~F}$ & $\overline{\text { Caesarean section }}$ & No & -5.2 & IGHD & Normal \\
\hline $2^{b}$ & GHRHR & $\mathrm{F}$ & Normal & $\begin{array}{l}\text { Affected } \\
\text { brother }\end{array}$ & -5.8 & IGHD & $\begin{array}{l}\text { Anterior pituitary } \\
\text { hypoplasia, NVPP }\end{array}$ \\
\hline 3 & PROP1 & M & Normal & No & -7.8 & GH, TSH, ACTHp & $\begin{array}{c}\text { Anterior pituitary } \\
\text { hypoplasia, TPP }\end{array}$ \\
\hline 4 & GLI2 & M & $\begin{array}{l}\text { Caesarean section, } \\
\text { hemorrhage } \\
\text { during labour }\end{array}$ & $\begin{array}{l}\text { Reported } \\
\text { short } \\
\text { stature }\end{array}$ & -4.4 & IGHD & EPP \\
\hline 5 & OTX2 & M & Normal & No & -6.1 & IGHD & $\begin{array}{l}\text { EPP, septo-optic } \\
\text { dysplasia }\end{array}$ \\
\hline
\end{tabular}

Associated complex phenotype

Deafness

Absent

Absent

Absent

Microphthalmia, nystagmus, neuropsychomotor developmental delay

aBorn to consanguineous healthy parents; ${ }^{b}$ parents came from the same small village.

EPP, ectopic posterior pituitary; IGHD, isolated growth hormone deficiency; MRI, magnetic resonance imaging; NVPP, non visualized posterior pituitary; TPP, topic posterior pituitary.

https://ec.bioscientifica.com https://doi.org/10.1530/EC-19-0085 (c) 2019 The authors Published by Bioscientifica Ltd

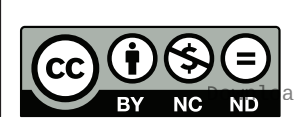

This work is licensed under a Creative Commons Attribution-NonCommercial-NoDerivatives 4.0 elnternationab bicense.ifica . com at $04 / 26 / 2023 \quad 06: 26: 45 \mathrm{AM}$ 
which is therefore one of the first candidate genes to be screened in consanguineous cases (10).

We found two pathogenic variants in compound heterozygous state in PROP1 [c.301_302delAG];[c.109+1G>A] in one subject. Whereas c.301_302delAG is the most common PROP1 variant worldwide due to a founder effect, the c.109+1G $>$ A variant was first found by this panel and recently published as a novel variant by our Unit together within a cohort of Brazilian patients $(7,11)$. Although there is an increased prevalence of familial cases and consanguinity among patients with CPHD due to PROP1 variants, the patient described here is a sporadic case and the only affected member of his family (7).

One patient in our cohort had a pathogenic stop codon variant in GLI2 (p.Glu561*) that predicts a truncated protein with loss of the zinc finger and transactivation domains. Variants in GLI2 have incomplete penetrance and can lead to complex midline defects, holoprosencephaly (HPE), cleft palate, polydactyly and CPHD with variable phenotypes $(12,13)$. Our patient presents a mild phenotype with only IGHD, and no craniofacial defects.

A novel nonsense variant was identified in OTX2 (p.Gln107*) gene in heterozygous state, predicting a truncated protein with the loss of 642 amino acids. Variants in OTX2 were associated to severe ocular malformations such as anophthalmia, microphthalmia and variable degrees of hypopituitarism. Most patients with OTX2 mutations also exhibit brain anomalies and/or seizures that are not present in our case (14).

Until now, only one study used a target gene panel for the diagnosis of a cohort of patients with $\mathrm{CH}$ : 51 patients from 44 independent pedigrees were evaluated for mutations using a target sequence panel, in which genes were captured using smMIPS (single-molecule molecular inversion probe capture assay). In two families with IGHD phenotype, the same heterozygous mutation in GH1 gene (p.Arg209His) was identified (15).

Other studies used target panel or whole exome sequencing to study patients with short stature due to different etiologies including few patients with GHD. Dauber et al. sequenced 1077 genes in 192 patients (31 with CPHD) and found four pathogenic variants in PTPN11 and IGF1R genes (16). Hauer et al. sequenced 200 patients with short stature who underwent extensive prior endocrinological and diagnostic workup to exclude defects of the growth hormone pathway and identified one variant in the GHSR gene (17). At last, another study performed exome-sequencing on ten patients with CPHD and their unaffected parents and suggested SLC2OA1 and SLC15A4 as new candidate genes (18).

Using a target gene panel in large cohorts allows the screening of many genes simultaneously with higher accuracy avoiding the misinterpretation caused by the lack of phenotype-genotype correlation. Therefore, we believe that this approach has advantages for the genetic diagnosis when compared to the candidate-gene approach.

The diagnosis of GH deficiency is complex and usually involves auxological, hormonal and imaging studies (19). If recent advances in genetic studies will curtail this diagnostic odyssey remains to be elucidated. The modest positive rate of genetic screening of $\mathrm{CH}$ (4\%: this study) obtained with gene panels indicates that this genetic tool still cannot replace the clinical diagnosis of $\mathrm{CH}$.

We conclude that a custom-designed target gene panel is an efficient method to screen simultaneously variants of biological and clinical relevance for congenital GH deficiency. A genetic diagnosis was possible in 5 out of 117 (4\%) patients of our cohort. We identified novel variants in GHRHR, PROP1, OTX2 and GLI2. Further studies are necessary to understand the participation of other genetic, epigenetic phenomena and/or environmental factors in the aetiology of most patients with $\mathrm{CH}$.

\section{Declaration of interest}

The authors declare that there is no conflict of interest that could be perceived as prejudicing the impartiality of the research reported.

\section{Funding}

The National Council of Technological and Scientific Development (CNPq) - Brazil, supported this work: grant number 305743/2011-2 to BBM and 301871/2016-7 to AALJ. São Paulo Research Foundation (FAPESP) also supported this work: grant number 2013/03236-5 to AALJ; 2015/26563-7 to LRC; grant 2013/02162-8and grant SELA 2014/50137-5.

\section{References}

1 Kelberman D, Rizzoti K, Lovell-Badge R, Robinson IC \& Dattani MT. Genetic regulation of pituitary gland development in human and mouse. Endocrine Reviews 200930 790-829. (https://doi.org/10.1210/ er.2009-0008)

2 Fang Q, George AS, Brinkmeier ML, Mortensen AH, Gergics P, Cheung LY, Daly AZ, Ajmal A, Pérez Millán MI, Ozel AB, et al. Genetics of combined pituitary hormone deficiency: roadmap into the genome era. Endocrine Reviews 201637 636-675. (https://doi. org/10.1210/er.2016-1101)

3 Crisafulli G, Aversa T, Zirilli G, De Luca F, Gallizzi R \& Wasniewska M. Congenital hypopituitarism: how to select the patients for genetic analyses. Italian Journal of Pediatrics 20184447. (https://doi.org/10.1186/s13052-018-0484-y)

4 De Rienzo F, Mellone S, Bellone S, Babu D, Fusco I, Prodam F, Petri A, Muniswamy R, De Luca F, Salerno M, et al. Frequency of genetic 
defects in combined pituitary hormone deficiency: a systematic review and analysis of a multicentre Italian cohort. Clinical Endocrinology 201583 849-860. (https://doi.org/10.1111/cen.12849)

5 Otto AP, França MM, Correa FA, Costalonga EF, Leite CC, Mendonca BB, Arnhold IJ, Carvalho LR \& Jorge AA. Frequent development of combined pituitary hormone deficiency in patients initially diagnosed as isolated growth hormone deficiency: a long term follow-up of patients from a single center. Pituitary 201518 561-567. (https://doi.org/10.1007/s11102-014-0610-9)

6 Richards S, Aziz N, Bale S, Bick D, Das S, Gastier-Foster J, Grody WW, Hegde M, Lyon E, Spector E, et al. Standards and guidelines for the interpretation of sequence variants: a joint consensus recommendation of the American College of Medical Genetics and Genomics and the Association for Molecular Pathology. Genetics in Medicine 201517 405-424. (https://doi.org/10.1038/gim.2015.30)

7 Madeira JLO, Nishi MY, Nakaguma M, Benedetti AF, Biscotto IP, Fernandes T, Pequeno T, Figueiredo T, Franca MM, Correa FA, et al. Molecular analysis of Brazilian patients with combined pituitary hormone deficiency and orthotopic posterior pituitary lobe reveals eight different PROP1 alterations with three novel mutations. Clinical Endocrinology 201787 725-732. (https://doi.org/10.1111/ cen.13430)

8 Salvatori R, Hayashida CY, Aguiar-Oliveira MH, Phillips JA, Souza AH, Gondo RG, Toledo SP, Conceicão MM, Prince M, Maheshwari HG, et al. Familial dwarfism due to a novel mutation of the growth hormone-releasing hormone receptor gene. Journal of Clinical Endocrinology and Metabolism 199984 917-923. (https://doi. org/10.1210/jcem.84.3.5599)

9 Marui S, Trarbach EB, Boguszewski MC, França MM, Jorge AA, Inoue $\mathrm{H}$, Nishi MY, de Lacerda Filho L, Aguiar-Oliveira MH, Mendonca BB, et al. GH-releasing hormone receptor gene: a novel splice-disrupting mutation and study of founder effects. Hormone Research in Paediatrics 201278 165-172. (https://doi. org/10.1159/000342760)

10 Alatzoglou KS, Turton JP, Kelberman D, Clayton PE, Mehta A, Buchanan C, Aylwin S, Crowne EC, Christesen HT, Hertel NT, et al. Expanding the spectrum of mutations in GH1 and GHRHR: genetic screening in a large cohort of patients with congenital isolated growth hormone deficiency. Journal of Clinical Endocrinology and Metabolism 200994 3191-3199. (https://doi.org/10.1210/jc.20082783)

11 Dusatkova P, Pfäffle R, Brown MR, Akulevich N, Arnhold IJ, Kalina MA, Kot K, Krzisnik C, Lemos MC, Malikova J, et al. Genesis of two most prevalent PROP1 gene variants causing combined pituitary hormone deficiency in 21 populations. European Journal of Human Genetics 201624 415-420. (https://doi.org/10.1038/ejhg.2015.126)

12 Arnhold IJ, França MM, Carvalho LR, Mendonca BB \& Jorge AA. Role of GLI2 in hypopituitarism phenotype. Journal of Molecular Endocrinology 201554 R141-R150. (https://doi.org/10.1530/JME-150009)

13 Babu D, Fanelli A, Mellone S, Muniswamy R, Wasniewska M, Prodam F, Petri A, Bellone S, Salerno MC \& Giordano M. Novel GLI2 mutations identified in patients with Combined Pituitary Hormone Deficiency (CPHD): evidence for a pathogenic effect by functional characterization. Clinical Endocrinology 201990 449-456. (https:// doi.org/10.1111/cen.13914)

14 Rizzoti K. Genetic regulation of murine pituitary development. Journal of Molecular Endocrinology 201554 R55-R73. (https://doi. org/10.1530/JME-14-0237)

15 Pérez Millán MI, Vishnopolska SA, Daly AZ, Bustamante JP, Seilicovich A, Bergadá I, Braslavsky D, Keselman AC, Lemons RM, Mortensen $\mathrm{AH}$, et al. Next generation sequencing panel based on single molecule molecular inversion probes for detecting genetic variants in children with hypopituitarism. Molecular Genetics and Genomic Medicine 2018. (https://doi.org/10.1002/mgg3.395)

16 Wang SR, Carmichael H, Andrew SF, Miller TC, Moon JE, Derr MA, Hwa V, Hirschhorn JN \& Dauber A. Large-scale pooled nextgeneration sequencing of 1077 genes to identify genetic causes of short stature. Journal of Clinical Endocrinology and Metabolism 201398 E1428-E1437. (https://doi.org/10.1210/jc.2013-1534)

17 Hauer NN, Popp B, Schoeller E, Schuhmann S, Heath KE, HisadoOliva A, Klinger P, Kraus C, Trautmann U, Zenker M, et al. Clinical relevance of systematic phenotyping and exome sequencing in patients with short stature. Genetics in Medicine 201820 630-638. (https://doi.org/10.1038/gim.2017.159)

18 Simm F, Griesbeck A, Choukair D, Weiß B, Paramasivam N, Klammt J, Schlesner M, Wiemann S, Martinez C, Hoffmann GF, et al. Identification of SLC20A1 and SLC15A4 among other genes as potential risk factors for combined pituitary hormone deficiency. Genetics in Medicine 201820 728-736. (https://doi.org/10.1038/ gim.2017.165)

19 Grimberg A \& Allen DB. Growth hormone treatment for growth hormone deficiency and idiopathic short stature: new guidelines shaped by the presence and absence of evidence. Current Opinion in Pediatrics 201729 466-471. (https://doi.org/10.1097/ MOP.0000000000000505)

Received in final form 21 March 2019

Accepted 4 April 2019

Accepted Preprint published online 4 April 2019 https://ec.bioscientifica.com https://doi.org/10.1530/EC-19-0085 (c) 2019 The authors Published by Bioscientifica Ltd
This work is licensed under a Creative Commons Attribution-NonCommercial-NoDerivatives 4.0 internationab sicense ifica com at 04/26/2023 06:26:45AM 